\title{
FATHOM
}

\section{Hardy in France: Belles Lettres and Popular Culture}

Hardy en France : des Belles Lettres à la culture populaire

\section{Peggy Blin-Cordon and Laurence Estanove}

\section{(2) OpenEdition}

\section{Journals}

Electronic version

URL: http://journals.openedition.org/fathom/841

DOI: 10.4000/fathom.841

ISSN: 2270-6798

\section{Publisher}

Association française sur les études sur Thomas Hardy

\section{Electronic reference}

Peggy Blin-Cordon and Laurence Estanove, « Hardy in France: Belles Lettres and Popular Culture », FATHOM [Online], 5 | 2018, Online since 22 April 2018, connection on 20 April 2019. URL : http:// journals.openedition.org/fathom/841; DOI : 10.4000/fathom.841 


\title{
Hardy in France: Belles Lettres and Popular Culture
}

\author{
Hardy en France: des Belles Lettres à la culture populaire
}

Peggy Blin-Cordon and Laurence Estanove

\section{EDITOR'S NOTE}

This article was originally published in The Hardy Review 17.2 (Autumn 2015): 15-32. It is reproduced here by special authorization from the Hardy Review editor.

1 One experience common to all doctoral students is having to explain your dissertation subject to relatives and acquaintances foreign to the discipline. When studying literature, the existence of a national or international literary canon can usually serve as a point of reference to guide the lay(wo)man. Yet for a French student working on Thomas Hardy, this only rarely proves efficient, and both of us discovered early in our research that the surest way to give people a sense of what our hours of intense reading might be like was to invoke Roman Polanski. His 1979 adaptation of Tess is undoubtedly the reference to Hardy most French people would know, if any. Tess is, after all, a French film, its main producer having been the late famous director Claude Berri. It was also co-written by French screenwriter Gérard Brach (a regular collaborator of Polanski's), its score composed by Philippe Sarde, and a majority of the crew (assistant director, art and sound etc.) was French. As such, it won three awards (best film, best director and best cinematography) at the French national "César" film ceremony in 1980.

2 Aesthetically and visually, Tess offers a representation of the mid-nineteenth century English countryside that is indeed a reconstruction in both time and space, as the film was shot exclusively in France, mainly on location in the northwestern regions of Brittany and Lower Normandy. A lot of this "Frenchness" is incidental, a consequence of Polanski's personal life and judicial situation at the time. ${ }^{1}$ Yet Tess is also one of those classics that are regularly broadcast on French TV, and the film was digitally restored and re-issued in cinemas as well as DVD and Blu-Ray in 2012. The DVD bonuses include a 
documentary by French journalist Serge July, Il était une fois Tess, one of a series which aimed at having a film resonate with its time. In a 2009 interview, July explained the Frenchness of Tess, or at least how the film resonated with the French society of the late 1970s: "Polanski's Tess, a period film set in the $19^{\text {th }}$ century, is, in its own way, a testimony to late 1970s France, since the film, which is so essentially rural, was shot just at the time when rural society was disappearing in our country" (Odicino; translation ours) ${ }^{2}$.

ef storyteller, a talent thus naturally transferred to the gripping narrative mode of filmmaking; yet the very cinematic power of Hardy's work, his vision and sense of kinetics are not restricted to his skills as a novelist. They've been appealing to all reading publics, whatever the culture, context, or time, because of "something else and something more", what Charles Du Bos pointed as "the sense of life in general", (Du Bos 854; translation ours) ${ }^{3}$ the very essence of universality.

4 What follows is not intended as an exhaustive account of the distribution and reception of Hardy's work in France. It is rather a selective outline (counting a few oddities showing Hardy's presence where least expected) of what, in the discreet yet persistent presence of his writings in the French cultural and academic landscape, may testify to his universality and account for the recent revived interest in him, manifest mostly in the creation and activities of the French Association for Thomas Hardy Studies (FATHOM) but also more tenuously in a few repercussions on popular culture. Hopefully, this may encourage some further examination of the relationship between Hardy and France.

\section{Cinema and popular culture}

5 If we further dwell on the subject of Hardy on screen, we might want to mention a recent manifestation of his presence in French popular culture, that is the French release (June 3 rd, 2015) of Danish film director Thomas Vinterberg's Far from the Madding Crowd. The film stars Carey Mulligan as Bathsheba, Tom Sturridge as Sergeant Troy, and quite surprisingly for French viewers, Matthias Shoenaerts as Gabriel Oak. Schoenaerts, though not French but Belgian, is one of the French-speaking budding talents who count in the French film industry ${ }^{4}$. It is also worth noting that the part of Bathsheba is played by an actress who is allegedly better known in France than Julie Christie was for the release of Schlesinger's own 1967 adaptation ${ }^{5}$. Julie Christie, the icon of Great Britain in the 1960s, possibly had a more confidential notoriety in France compared to Mulligan's today. The young Hollywood star appears as quite a "mainstream" ambassadress for Hardy in France, probably even more than Kate Winslet in her time, when Michael Winterbottom's adaptation of Jude was released ${ }^{6}$. Consequently, her reputation only could attract spectators in cinemas, and thus make Hardy better known for an audience who have never heard, or possess very little knowledge of the author. For some French people, Bathsheba may be remembered as bearing the features of Carey Mulligan, in the same way that for others, Tess is and always will be Nastassja Kinski.

Notably enough, Vinterbeg's adaptation triggered the release of a new pocket edition of the novel, Loin de la foule déchaînée, its front cover displaying a picture of Mulligan and Schoenaerts along with an explicit reference to the film. In its time, the $1996 \mathrm{film}$ adaptation of Jude had also prompted the re-edition of the 1901 French translation by Firmin Roz, with the poster of the film displaying couple Eccleston and Winslet as new 
front cover (Hardy 1996). No doubt the caption "based on Thomas Hardy's classic love story" as featured in the trailer for Vinterberg's film will also appeal to a large audience.

Although it might appear at first as cultural epiphenomena when we consider the presence of the author in the French artistic background, such films based on Hardy's novels contribute - for better or worse - to the dissemination and positioning of Hardy's works in French popular culture. Which also seems to be the consequence of the 2013 French edition of an abridged version of Tess aimed at a younger readership, since the novel was released in a collection for young adults entitled "Black Moon" and described as "the collection for readers keen to experience strong emotions" (Hardy 2013) ${ }^{7}$. The hint at the film adaptation by Polanski appears in the shortened title of the book, echoing the movie, and is blatant on the front cover showing a picture of a back-lit young woman in a romantic haze, bearing a strong resemblance to a younger N. Kinski and wearing the exact same dress as one of those sported by the latter in the film.

What is conspicuous in the way Hardy's novel has recently been marketed, whether it be via the embodiment of one of his heroines by Hollywood stars or the release of one of his masterpieces as young adult fiction, is that very progressively, Hardy has been infusing in French culture through popular media since the early 1980 s.

9 As we have just seen, sometimes in unexpected circumstances, reception is naturally linked to diffusion, hence of course to the accessibility of the texts, and therefore to the translations of an author's works. Entire books or dissertations could (and certainly ought to) be devoted to examining the French translations of Hardy's works - linguistically speaking of course, but also from an editorial perspective: one may study how the very first Hardy novel translated into French was actually The Trumpet Major, whose historical recapturing of the Napoleonic era certainly offers an interesting entry point into the contemporary definition of readers' expectations; how out of the fourteen novels published by Hardy, only one - A Laodicean - remains untranslated today; how Far from the Madding Crowd initially bore the glamorous title of Barbara, after its eponymous renamed heroine; how The Hand of Ethelberta appeared in 1931 under the misguiding title "Had He Insisted" (S'il avait insisté) and has known no subsequent edition since, as is incidentally also the case of Under the Greenwood Tree. The case of Tess is particularly interesting in that despite its being the most famous Hardy novel in France and most often re-published, read and studied, it has never been re-translated in full ${ }^{8}$ since Madeleine Rolland (sister of writer Romain Rolland) delivered her version, duly "authorized by the author", in 1901 (Hardy 1901).

\section{Hardy and contemporary French writers: Zola, Hugo, Proust}

10 Tess has again been central to a recent revived interest in Hardy from a purely academic viewpoint as was shown first in 2008 by the choice of the novel as part of the national syllabus for the Agrégation in Comparative Literature, coupled with Emile Zola's Nana (1880) and Theodor Fontane's Effi Briest (1894) to explore the question of "Female destinies in the context of European Naturalism". Parallels between Hardy and contemporary French writers have not always been convincing and accurate. Here, the problem is of course the apparently undisputed definition of Hardy as a naturalist; yet on the other hand there are some extremely good points to be made from a joint exploration 
of three female characters as drawn by the hands of three contemporary European novelists.

When parallels with Zola were made in Hardy's own lifetime, they appeared solely in harsh reviews and were systematically made with little justification other than base attack on indecency, most notably so when criticizing Jude. Zola is the undisputed standard bearer and main initiator of the naturalist trend, a writer who influenced generations of authors worldwide, including in Britain. The strained artistic proximity between Hardy and Zola was much condemned by the former. Hardy obviously resented the association, so much so that he openly evoked his disapproval in "Candour in English Fiction", and even more markedly in "The Science of Fiction" where he mainly argued that literature does not need science or accurate descriptions to make the reader fathom reality, thus offering an answer to Zola's Roman expérimental (The Experimental Novel, 1881). Naturalism and Zola did trigger a great many debates in the 1890s, and Hardy directly refers to Zola when condemning naturalism in the essay in strong words:

As this theory of the need for the exercise of the Dædalian faculty for selection and cunning manipulation has been disputed, it may be worth while to examine the contrary proposition. That it should ever have been maintained by such a romancer as M. Zola, in his work on the Roman Expérimental, seems to reveal an obtuseness to the disproof conveyed in his own novels which, in a French writer, is singular indeed. To be sure that author - whose powers in story-telling, rightfully and wrongfully exercised, may be partly owing to the fact that he is not a critic - does in a measure concede something in the qualified counsel that the novel should keep as close to reality as it can; a remark which may be interpreted with infinite latitude, and would no doubt have been cheerfully accepted by Dumas père or Mrs. Radcliffe. It implies discriminative choice; and if we grant that we grant all. But to maintain in theory what he abandons in practice, to subscribe to rules and to work by instinct, is a proceeding not confined to the author of Germinal and La Faute de l'Abbé Mouret. (Brennecke 86-87)

Even after such violent criticism, the reviews of Hardy's last novels almost systematically included a reference to Zola, the critics seldom resisting the pleasure of inserting a bon mot in French, often fraught with sexual innuendo. Take, for example, the review of Jude in World, referring to Zola not only for his generic stance but also for the amoral aspects of the French author's probably most sulphurous novel of the Rougon-Macquart series. The reviewer stated indeed that Hardy had based himself on "the methods of Zola and Tolstoi - Zola of La Terre" ("Hardy the Degenerate", World, 13 November 1895; quoted in Millgate 341). Another reviewer wrote that Hardy's Jude was similar to Zola's novels "which disgust rather than allure," and that Hardy had actually succumbed to Zola's "poisoned flower of lubricité," his novel also relying on "an ugly weed called gauloiserie" (R. Y. Tyrrell, Fortnightly Review, June 1896; quoted in Cox 302). What is mainly pointed at in the reviews is the seeming generic link between the two authors, but in truth, it is most of all the transgressive quality of their art, their ability to shock and their apparent propensity to advocate loose morals.

13 Another monument of French literature one might feel inclined to conjure up, perhaps more rightfully, is Victor Hugo. Though the parallels between them might not be so striking, it is worth considering how Hardy and Hugo - remarkable storytellers of their country and their time - both had that distinctive trait of being at once novelists and poets. Very recently, Marie Panter precisely wrote a $\mathrm{PhD}$ in French Comparative Studies showing how the two writers shared the same poetics of the novel (Panter). The two never met, but there is proof that Hardy had actually read Hugo and highly respected 
him. In 1902, on the occasion of the centenary of Hugo's birth, he wrote in a French review: "His memory must endure. His works are the cathedrals of literary architecture, his imagination adding greatness to the colossal and charm to the small." (F.E. Hardy 92) Such a tribute is a noteworthy compliment coming from a man of letters who placed so much of his craftsmanship as a former stonemason in his novel writing. In 1903, he addressed another comment on Hugo in a letter to Sir George Douglas. Explicitly stating his admiration, he paid homage to Hugo's radicalism, another aspect that the two artists shared:

I am a Victor-Hugo-ite still. If he often crosses the line into the extravagant his ideas are so arresting even when he does so cross that they never fail to hold me. As you say, his misérables are not so real as Dickens's, but they show, to my mind, one great superiority, that of universality, while those of Dickens express the particular only. (Purdy 81)

Conveying a sense of "the great superiority of universality" is indeed a feature that is undeniably both Hardy's and Hugo's, justifying the instinct one might have of likening the two when introducing Hardy to a French neophyte?

Even more convincing and justified have been connections with Proust. A number of studies have examined the famous reciprocal admiration of both writers or analyzed their works jointly. In recent years, this is the case, among others, of Diane de Margerie, a translator of several Hardy texts who devoted the final part of her aptly named study Proust et l'obscur to the parallels between Proust and Hardy, as well as Proust and French painter Gustave Moreau. Given the visual force of Hardy's writing, amply analyzed by several critics, it is no surprise to see him thus appear alongside a painter. Incidentally, it is also a French painter, Jacques-Emile Blanche (1861-1942), who offered both Hardy and Proust an enduring presence in people's minds: Blanche's Portrait de Marcel Proust (1892), now exhibited at the Musée d'Orsay ${ }^{10}$, is by far the most famous representation of the French writer, while Blanche's sketch portrait of Hardy is now in the Tate collection, a second "finished" version, painted later by Blanche, being held by the Manchester City Art Gallery ${ }^{11}$.

16 As is widely known, Hardy himself established connections between his writing and Proust's by referring to the essentially subjective nature of love as exhibited in The Well Beloved, copying in July 1926 two quotations from Proust's À l'Ombre des jeunes filles en fleur as given in the magazine Marsyas ${ }^{12}$. Proust's own direct reference to Hardy in La Prisonnière (published posthumously in 1923) famously pointed to the "geometry" of the latter's art - its "stonemason geometry"13.

I came back to Hardy's stone-cutters. "You remember them in Jude the Obscure, but do you remember how in The Well-Beloved the blocks of stone that the father quarries on the island are brought by water and piled up in the son's workshop where they become statues; how in A Pair of Blue Eyes there are the parallel graves, and the parallel lines of the ship, and the row of wagons where the lovers are next to the corpse, and the parallelism between The Well-Beloved, where the hero loves three women, and A Pair of Blue Eyes, where the woman loves three men, and so on, all those novels that could be superimposed on each other, like the houses piled vertically, one above the other, on the rocky soil of the island? [...]" (Proust 346) ${ }^{14}$ 


\section{Contemporary reviewers: French champions of Hardy's work}

17 This ties in with the sense that Hardy's work is always best thought of in visual terms or through spatial projections. Nowhere is the sheer force of Hardy's pictorial and spatial writing better staged than in The Dynasts. As marginal as that opus might appear, it nonetheless drew the fascinated attention of one French reviewer, Valéry Larbaud, in $1908^{15}$. Such Franco-British literary connection was naturally not unusual at the time, and that one in particular is the subject of an article by David Roe, an extremely enlightening read both as regards the reception of Hardy in France and the French literary journalism of the time. What surfaces is that Hardy was, at the turn of the $20^{\text {th }}$ century, still little known in France, the French literary taste of the time being more attracted to Russian flavours. Yet a few critics, mostly related to the famous periodical Mercure de France, followed the progress of The Dynasts as it was published ${ }^{16}$, and Roe sees Larbaud's eightpage article as "an excellent introduction" to it, the French critic acting as both "scholar and explicator" of Hardy's work (Roe 89). Very interestingly for us here, Roe points at Larbaud's perception of Hardy as a European rather than an English writer:

In his later references to Hardy, Larbaud chose to take him completely out of the English context and insist on his stature as a European writer. He did so in a note on the selection of a new Poet Laureate in 1913:

Thomas Hardy, qui est sans doute, depuis la mort de Tolstö̈, le plus grand nom de la littérature européenne, est justement trop européen pour n'être que le poète-lauréat de l'Angleterre.

[Thomas Hardy, who is doubtless, since the death of Tolstoy, the greatest name in European literature, is, precisely, too European to be only the Poet Laureate of England.] (La Nouvelle Revue Française, October 1913; Roe, 96) ${ }^{17}$

Interest in Hardy among his French contemporaries and counterparts would thus deserve further investigation, since his work and name were not entirely absent from literary reviews of the time - more so once he had given up novel writing. Several French writers, influential critics and translators of Hardy in the first thirty years of the $20^{\text {th }}$ century asserted with one accord that his work represented a landmark in European literature. In Larbaud, Du Bos, Jaloux, Roz or Davray ${ }^{18}$, Hardy found real champions of his work in France, even during the times when his last novels were causing serious havoc in his own country. Little by little, he came to be consecrated and appeared less marginal in the French cultural landscape. Firmin Roz, the first man of letters to translate Jude in French, very well detected the change in mentalities imposed by Hardy's perception of the society and gratified readers of $L a$ Revue Française, which published Jude l'obscur in 1900, with a committed preface. In those lines, he strongly argued in the defence of Hardy against the puritanism of late Victorian Britain, condemning the general reaction to the book in Hardy's country, but also more specifically targeting the review of the Athenaeum, or Mrs Oliphant's criticism in Blackwood's Magazine for example. He also insisted on the visionary dimension of Hardy's novel and on the author's compassion and empathy:

No other work appears to me as less dogmatic. It seems impossible to me to bring out of it either the glorification or condemnation of free love. [...] What we have here is a thinker, both a poet and an artist. He observes and ponders.

When dealing with Hardy, meditation combines with compassion. An immense pity fills his heart, and soon, this thought takes over any other thought, and a humble 
thought it is, much deeper than any system, a much more human thought too, much more moving [...]. (Roz 322-323; translation ours) ${ }^{19}$ devoted critic of Victorian literature whose "Lectures on Hardy" delivered in 1925 did not
appear in print until that special tribute number, and only in a much shorter version (Du Bos 833-834). Sadly, they have not been translated into English, and one of their sole examination, provided by Bénédicte Coste in 2011, is also inaccessible to those who do not read French. Yet Du Bos's study of Hardy is among the most powerful to have been written - a unique appreciation and incredibly insightful understanding of Hardy's writing, also unique in that $\mathrm{Du}$ Bos unquestioningly combined novels and poems in his analysis. He thus seemed to suggest that only an all-inclusive study of Hardy's entire oeuvre could do his writing justice:

Hardy's enduring cosmic viewpoint, his faithful devotion to that viewpoint, barely ever implies any radical differentiation between his various works; and that is why, in the rich aquarium of our memory where so many masterpieces lead their mysterious lives, the overall impression left by Hardy's entire work is more powerful yet than the impression left by whichever single one of his greatest books if considered separately. (Du Bos 847; translation ours) ${ }^{21}$

$\mathrm{Du}$ Bos also beautifully pointed at the essentially compassionate spirit of Hardy's writing, at how the author's modernity is inextricably tied in to the "adamantine honesty of his soul" (Du Bos 833) ${ }^{22}$, and at "that meaning of life in general with which Hardy both refreshes and stifles us, [and which] is always, ultimately, a vivifying, healthy, salty breath of air" (Du Bos 854; translation ours) ${ }^{23}$. 
Celebrated by literary reviewers, Hardy's work also gradually became a legitimate academic concern, as symbolically proven by the preface to Jude l'obscur written by Edmond Jaloux in 1931. Jaloux was an académicien, a member of the French Academy of Letters, the respectable institution founded in the $17^{\text {th }}$ century to regulate matters relative to the French language, notably via the publication of the official dictionary of the French language. The members of the academy are valued writers, philosophers and thinkers and even scientists whose works have remarkably honoured the French language. They have included, among others, Voltaire, Victor Hugo, Marguerite Yourcenar... Admittedly, Edmond Jaloux is not a very well-know académicien, either in France or abroad, yet his name is worth mentioning for, as a critic, he was dedicated to broadening the French literary horizons to foreign literatures, most particularly promoting the work of Rainer Maria Rilke in the country. In his promotion of British literature in the 1931 preface to Jude l'obscur, he surprisingly addresses the reader in quite similar terms to those used by Larbaud before him:

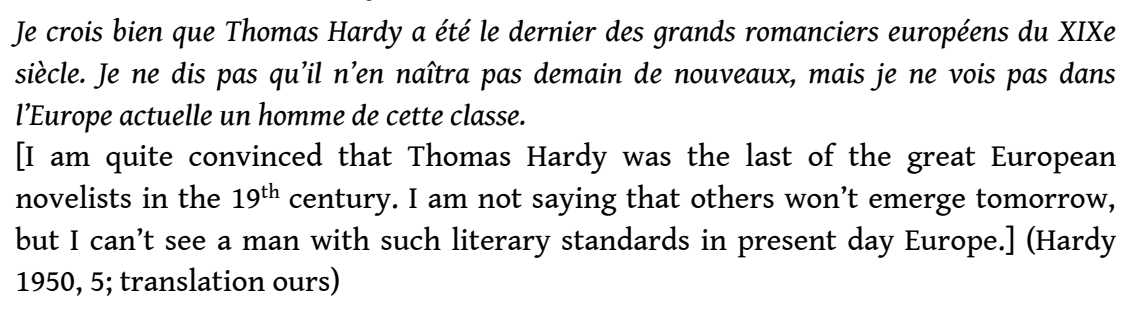

25 Jaloux not only introduces Jude in his preface, but also discusses (sometimes at length) a great variety of works by Hardy, proving his extensive knowledge of both poetry and prose, lesser known (Two on a Tower) and major (Tess) works. Echoing both Larbaud and Du Bos, he suggests that Hardy's work is best envisaged as a whole.

\section{Hardy criticism and interest in France since the 1980s}

After that relative concentration of interest, the number of studies in French devoted to Hardy - of whatever length - returned to its original scarcity, with only three PhDs completed between 1928 and the early 1980s: d'Exideuil's was followed in 1932 by the publication in Brussels of Louise De Ridder-Barzin's Le pessimisme de Thomas Hardy, and more than twenty years later, one finds an unpublished study by another woman, Blanche Jacquet, who analysed Hardy's work from a medical perspective in her dissertation La Médecine et les médecins dans l'œuvre de Thomas Hardy. L'œuvre de Thomas Hardy vue sous l'angle medical - a fascinating undertaking which would certainly deserve attention.

27 A thorough research might reveal more, but that seems to be the bare extent of interest in Hardy over several decades in France, leaving aside a few novels that were republished and new additions to the catalogue of translated works which appeared in the aftermath of Hardy's death: The Hand of Ethelberta (S'il avait insisté) in 1931, The Woodlanders (Les Forestiers) in 1932, The Mayor of Casterbridge (Le Maire de Casterbridge) in 1933. Another notable and impressive addition came out in 1947 with Les Dynastes.

Hardy's work also appeared in the popular form of radio dramatization, first with an adaptation of Jude broadcast by France Culture in the summer of 1969, yet rather timidly 
so since listeners had to wait a full thirteen years to hear the second adaptation, Tess being broadcast in the Spring of 1982.

Hence came the turn of 1980s which saw a definite revival of interest with several publications and new translations - one novel (Under the Greenwoord Tree), some poems and short stories - as well a new academic focus, undoubtedly led by the colossal and seminal work of Annie Escuret. In keeping with Du Bos's global vision of Hardy's work, Annie Escuret's first idea was to study the novels as well as the poetry, but the latter subject had been taken by a colleague, barring her from using it herself - a colleague who shamefully did not pursue his research. Yet what Annie delivered has been a goldmine to all ensuing Hardy scholars in France: her major contribution was not only to remind French academics of the tremendous power of Hardy's work in its humbling entirety, but also to offer a much-needed contextual study of that work, linking it to the scientific and philosophical upheavals of its time. Escuret's work is also a great piece in epistemocriticism, and remains sadly untranslated into English.

The 1980s was also the period when Hardy's writing found its way into the minds and pages of some French humanities scholars and thinkers for whom literature was nonetheless of primary concern. The most interesting case was certainly that of Yvonne Verdier, an ethnologist and sociologist who analysed Hardy's novels from an anthropological perspective in an unfinished study she left upon dying suddenly in 1989. Like Larbaud, she considered Hardy from a European perspective, explaining that "[e]ssentially Hardy invented - simultaneously to other European novelists [...] - a monographic eye" (Verdier 19; translation ours) ${ }^{24}$. To her, Hardy's novels thus combined the ethnographic vision of a community and its custom with the idea of individual destiny typical of great tragic literature. How Hardy moved "from rite to novel" (77) was thus the core of her analysis which forms a unique contribution that has mostly gone unnoticed so $\mathrm{far}^{25}$.

31 Verdier's attachment to community, place and geography resonates with the attachment to space prominent in the scarce but powerful references to Hardy delivered by French philosopher Gilles Deleuze. As self-proclaimed champion of Anglo-American literature, Deleuze lamented how the French novel "spends its time plotting points instead of drawing lines, active lines of flight or of positive deterritorialization," while "[t]he AngloAmerican novel is totally different. [...] Hardy to Lawrence, from Melville to Miller, the same cry rings out: Go across, get out, break through, make a beeline, don't get stuck on a point. Find the line of separation, follow it or create it, to the point of treachery." (Deleuze \& Guattari 186-187) ${ }^{26}$ In the Dialogues with Claire Parnet, he focused even more specifically on the way Hardy's characters may exemplify his notion of "individuation without subject." The extract deserves quoting in full:

Take as an example the case of Thomas Hardy: his characters are not people or subjects, they are collections of intensive sensations, each is such collection, a packet, a bloc of variable sensations. There is a strange respect for the individual, an extraordinary respect: not because he would seize upon himself as a person and be recognized as a person, in the French way, but on the contrary because he saw himself and saw others as so many 'unique chances' - the unique chance from which one combination or another had been drawn. Individuation without a subject. And these packets of sensations in the raw, these collections or combinations, run along the lines of chance, or mischance, where their encounters take place - if need be, their bad encounters which lead to death, to murder. Hardy invokes a sort of Greek destiny for this empiricist experimental world. Individuals, 
packets of sensations, run over the heath like a line of flight or a line of

deterritorialization of the earth. (Deleuze \& Parnet 39-40) academia before the 1990s. Yet the handful of doctoral dissertations and articles which have appeared since have been of decisive importance, covering the whole gamut of Hardyan colourings: Isabelle Gadoin offered an examination of the spatial and visual traits of Hardy's fiction through a complete pictorial and phenomenological redefinition of Wessex (1993); Thierry Goater explored the novels in the light of the dynamics of alienation that sustain them (2000); Stéphanie Bernard took an intertextual perspective by considering the pre-modernism of Hardy in parallel with the work of Joseph Conrad (2004); Peggy Blin-Cordon looked at the generic hybridity and experimentation of Hardy's novels and their context of publication (2005); Laurence Estanove took up the task of examining Hardy's poetry in the context of post-evolutionist intellectual history (2008); Nathalie Bantz devoted herself to the short stories as testing grounds of writing, with a particular focus on gender issues (2009); Gildas Lemardelé studied the structural presence of infernal and diabolical representations throughout several Hardy's novels (2013); and, as previously mentioned, Marie Panter chose the comparative approach by analysing the poetics of the novel in works by Victor Hugo, Theodor Fontane and Hardy (2013). The latest addition is due to come from Emilie Loriaux who is currently writing a doctoral dissertation looking at the poetic and philological connections between Hardy and William Barnes. In the past twenty years or so, this tenuous yet constant academic interest has also been sustained by enlightening contributions in article form by Catherine Lanone, Marc Porée, André Topia, and Paul Volsik.

The growing number of consistent researches on Hardy throughout the 1990s and 2000s definitely paved the way for what was to permanently revive and officialise the interest in Hardy in French academia: the birth of FATHOM, the French Association for Thomas Hardy Studies. FATHOM was created in June 2009 at the Hardy conference held by Stéphanie Bernard in Rouen, and was in reality the outcome of conferences held in the previous years in Montpellier by Annie Escuret (2008), in Lyon by Annie Ramel (2007), and in Toulouse by Catherine Lanone (2006). Annual conferences have been organized since, and in 2013 the association also launched its online peer-reviewed journal, http:// journals.openedition.org/fathom. Devoted to publishing conference proceedings and theme-based issues, the journal also welcomes submissions of individual contributions, both in English and in French.

Two years after the Agrégation in Comparative Literature, 2010 marked further institutional interest and recognition of Hardy with the choice of Far from the Madding Crowd for the national syllabus of the Agrégation in English Studies. For several years now, the Agrégation English syllabus has been including the joint study of a novel and film. Interestingly again, it was John Schlesinger's own 1967 adaptation which was chosen in 2011, thus confirming the continuing interest of French academia for the cinematic potential of Hardy's writings. In addition to several publications specifically devoted to Far from the Madding Crowd for the Agrégation, Thierry Goater's Thomas Hardy. Figures de l'aliénation, which came out in late 2010, offered the first monograph on Hardy's novels to have appeared in more than fifty years, and Nathalie Bantz ideally completed it the following year with her own Les Nouvelles de Thomas Hardy. Stratégies narratives d'une écriture sous contrainte, devoted to Hardy's short stories. Even more recently and this time in English rather than French, Annie Ramel has also just delivered her psychoanalytical 
reading of Hardy in The Madder Stain, released earlier this year by Dutch publishers Rodopi. Book-length Hardy French criticism has been so far extremely scarce - before those three books, one needs to go back to d'Exideuil's and Rider-Barzin's works published around the time of Hardy's death.

The creation of FATHOM has facilitated exchanges and collaborations between Hardy scholars across Europe, as shown by the Hardy seminar held at the ESSE Conference in Istanbul in 2012, and expertly co-convened by Annie Ramel, Isabelle Gadoin and Phillip Mallett. In the same year, the first conference devoted to Hardy's poetry was organized in France by Adrian Grafe at the University of Arras, again gathering scholars from across the world.

The interest in Hardy's poetry in France has always been much more limited compared to his fiction, an obvious reason naturally being that the translation of poetry is probably the trickiest, most demanding of all. Poetry is also a much less popular and accessible medium than novel writing, yet part of Hardy's poetic work is now featured in a widely distributed collection which might help its opening to the French public. Gallimard have indeed included Hardy in their notable poetry collection, publishing in July 2012 Poèmes du Wessex suivi de Poèmes d'hier et d'aujourd'hui et de La Risée du Temps - selections of poems from the three collections (Wessex Poems, Poems of the Past and the Present and Time's Laughingstocks) with the original pieces in English facing the translations. The latter are by French poet Frédéric Jacques Temple, and had actually been first published in two separate volumes by a small publisher, Éditions de la Différence, in 1991 (Poèmes du Wessex ) and 1993 (La Risée du Temps). One notable feature of the Gallimard edition is the highly questionable choice of a cover illustration, collaging a photograph of Hardy's head and a close-up of his eyes with the Union Jack as backcloth. This is certainly a sad misguided choice from the editor's part, and one which betrays a poor knowledge of what the book actually contains. One would imagine a reader ignorant of Hardy's poetical work catching a glimpse of that cover and probably thinking that this must be the work of a patriotic poet, or, with more subtle associations, that Hardy might at least be a true representative of a distinctive British - or English, as the French will inevitably say - culture and identity.

Such misreading of Hardy's relation to his country and culture is assuredly not a blunder to be found in Eric Christen and Françoise Baud's own translation of a carefully selected hundred poems by Hardy. Their Cent Poèmes, issued by a small Swiss publisher in November 2008, pauses to reflect on the contextual importance of each poem, pointing at connections between the poet's words, his life and time - something imperative if one aims to recapture that "meaning of life in general" which Hardy's poetic writing so powerfully conveys.

It is again with cinema that we wish to conclude here. A couple of years ago, Hardy found his way into the references quoted by French filmmaker Arnaud Desplechin for his film Jimmy P: Psychotherapy of a Plains Indian (2013). That might appear as a surprising connection to make, as the film is an adaptation of French psychoanalyst Georges Devereux's accounts of his treatment of a Native American war veteran in the aftermath of WW2 $2^{27}$. Yet almost all the interviews given by Desplechin while promoting that film had a reference to Hardy. Several times in particular, he referred to the model of the 
Hardyan tragic character - "a Thomas Hardy kind of feeling" (Titze). He also explained that he saw his characters as if they came from a Hardy novel, and that he aimed at giving protagonists from a humble background the nobility of characters from a Hardy novel (Dupont).

There might not be much that hasn't been considered already there: Hardy's skills in characterization go beyond the mere dynamics of efficient narrative and truthful storytelling. However, whether he anticipated psychoanalysis or not, what remains undeniable is the acuteness and permanence of Hardy's eye for the complex minutiae of life. He has provided us with timeless explorations of the human psyche that can appeal to all cultural contexts, periods and places - including the re-telling by a French filmmaker of a Blackfoot Native American's life in post-war USA.

That, too, is part of Hardy's ability to enlighten us universally with the meaning of life.

\section{BIBLIOGRAPHY}

Alley, Ronald, Catalogue of the Tate Gallery's Collection of Modern Art other than Works by British Artists, London: Tate Gallery and Sotheby Parke-Bernet, 1981.

Bantz, Nathalie, Les Nouvelles de Thomas Hardy. Stratégies narratives d'une écriture sous contrainte, Paris : Honoré Champion, 2011.

Bernard, Stéphanie, De Thomas Hardy à Joseph Conrad : vers une écriture de la modernité, unpublished PhD Diss., Université de Lyon 2, 2004.

Blin-Cordon, Peggy, Thomas Hardy et l'expérimentation générique. Desperate Remedies, The Return of the Native et A Laodicean, unpublished PhD Diss., Université de Paris 7, 2005.

Brennecke Jr., Ernest (ed.), Thomas Hardy: Life and Art, Essays, Notes, and Letters, New York: Greenberg, 1925.

Coste, Bénédicte, “Charles du Bos, lecteur de Thomas Hardy", Miranda [Online] 4 (2011), <http:// journals.openedition.org/miranda/2056> (last accessed 16 April 2018).

Cox, R. G. (ed.), Thomas Hardy, The Critical Heritage, London: Routledge \& Kegan Paul, 1970.

d'Exideuil, Pierre, Le Couple humain dans l'œuvre de Thomas Hardy: Essai sur la sexualité dans les romans, contes et poèmes du Wessex, Paris : Les Editions de la Revue Nouvelle, 1928.

d'Exideuil, Pierre, The Human Pair in the Work of Thomas Hardy: An Essay on the Sexual Problem as Treated in the Wessex Novels, Tales and Poems, introd. Havelock Ellis, trans. Felix W. Crosse, London: Humphrey Toulmin, 1929.

De Margerie, Diane, Proust et l'obscur, Paris : Albin Michel, 2010.

De Ridder-Barzin, Louise, Le pessimisme de Thomas Hardy, Bruxelles : Éditions de la Revue de l'Université de Bruxelles, 1932.

Deleuze, Gilles \& Claire Parnet, Dialogues II, trans. H. Tomlinson \& B. Habberjam, New York: Columbia UP, 2007. 
Deleuze, Gilles \& Félix Guattari, A Thousand Plateaus, trans. Brian Sassumi, Minneapolis: U of Minnesota P, 1987.

Du Bos, Charles, "Quelques traits du visage de Thomas Hardy" (1929), Approximations, Paris : Éditions des Syrtes, 2000, 827-855.

Dupont, Joan, “An Idiosyncratic Healer from Abroad Soothes a Troubled Indian”, The New York Times [Online] (20 May 2013), <www.nytimes.com/2013/05/21/arts/21iht-dupont21.html?_r=0> (last accessed 16 April 2018).

Eells, Emily, Proust's Cup of Tea: Homoeroticism and Victorian Culture, Aldershot \& Burlington: Ashgate, 2002.

Escuret, Annie, "Henry D-Davray and the Mercure de France", The Reception of H. G. Wells in Europe, eds. Patrick Parrinder \& John S. Partington, London: Bloomsbury Academic, 2013, 28-47.

Escuret, Annie, L'Euvre romanesque de Thomas Hardy, 1840-1928 : lectures, unpublished PhD Diss., Université de Montpellier 3, 1983.

Estanove, Laurence, La poésie de Thomas Hardy : une dynamique de la désillusion, unpublished PhD Diss., Université de Toulouse 2, 2008.

FATHOM, French Association for Thomas Hardy Studies, created in 2009, <http://fathomhardy.fr > (last accessed 16 April 2018).

Gadoin, Isabelle, Construction de l'espace fictif dans les "Romans de caractère et d'environnement" de Thomas Hardy. Espace représenté et espace représentant, unpublished PhD Diss., Université de Paris 3, 1993.

Goater, Thierry, Thomas Hardy. Figures de l'aliénation, Presses Universitaires de Rennes, 2010. Hardy, Florence Emily, The Life of Thomas Hardy: The Early Life of Thomas Hardy (1840-1891) \& The Later Years of Thomas Hardy (1892-1928), London: Studio Editions, 1994.

Hardy, Thomas, Cent Poèmes, trans. \& ed. Eric Christen and Françoise Baud, Vevey : Éditions de l'Aire, 2008.

Hardy, Thomas, Jude l'obscur, pref. Edmond Jaloux, trans. F. W. Laparra, Paris : Albin Michel, 1950. Hardy, Thomas, Jude l'obscur, trans. Firmin Roz \& Hélène Seyrès, Paris : l'Archipel, 1996.

Hardy, Thomas, Poèmes du Wessex suivi de Poèmes d'hier et d'aujourd'hui et de La Risée du Temps, trans. \& ed. Frédéric Jacques Temple, Paris : Gallimard, 2012.

Hardy, Thomas, Tess d'Urberville, trans. Madeleine Rolland, Paris : Hachette, 1901.

Hardy, Thomas, Tess, trans. Josette Chicheportiche, Paris : Hachette Jeunesse, 2013.

Hedgcock, Frank, Thomas Hardy, penseur et artiste : Essai de critique, Paris : Hachette, 1911.

Jacquet, Blanche, La Médecine et les médecins dans l'œuvre de Thomas Hardy. L'œuvre de Thomas Hardy vue sous l'angle medical, unpublished PhD Diss., Université d'Aix, 1954.

Lemardelé, Gildas, Représentations diaboliques et infernales dans les romans de Thomas Hardy: emprunts et metamorphoses, unpublished PhD Diss., Université de Caen, 2013.

McGarry, Pascale, "Pour une nouvelle géométrie du roman : le côté Thomas Hardy de Proust", Poétique 156.4 (2008) : 435-451.

Millgate, Michael, Thomas Hardy: A Biography Revisited, Oxford: OUP, 2004. 
Morgan, Rosemarie (ed.), The Ashgate Research Companion to Thomas Hardy, Farnham \& Burlington: Ashgate, 2010.

Odicino, Guillemette, "Les belles histoires de l'oncle Serge (July)", Télérama [Online] (26 June 2009), <http://television.telerama.fr/television/serge-july-raconte,44459.php> (last accessed 16 April 2018).

Panter, Marie, Le roman, poème du monde. Victor Hugo, Theodor Fontane, Thomas Hardy, unpublished PhD Diss., École Normale Supérieure de Lyon, 2013.

Proust, Marcel, The Prisoner, trans. Carol Clark, The Prisoner; The Fugitive, London: Penguin Classics, 2003.

Purdy, Richard Little \& Michael Millgate (eds.), The Collected Letters of Thomas Hardy, Volume 3, 1902-1908, Oxford: OUP, 1982.

Ramel, Annie, The Madder Stain: A Psychoanalytic Reading of Thomas Hardy, Brill, Rodopi, 2015.

Roe, David, "Valéry Larbaud, Thomas Hardy and The Dynasts, with two letters from Larbaud to Hardy”, Franco-British Cultural Exchanges, 1880-1940: Channel Packets, eds. Andrew Radford \& Victoria Reid, London: Palgrave Macmillan, 2012, 84-101.

Roz, Firmin, “Thomas Hardy et le roman de Jude l'obscur", La Revue hebdomadaire, $2^{\mathrm{e}}$ série, $4^{\mathrm{e}}$ année, tome VIII (juillet 1900).

Taylor, Richard H. (ed.), The Personal Notebooks of Thomas Hardy, London: Macmillan, 1979.

Titze, Anne-Katrin, “Arnaud Desplechin in Conversation, Part 2”, <www.eyeforfilm.co.uk/ feature/2013-10-22-interview-with-arnaud-desplechin-about-jimmy-p-feature-story-by-annekatrin-titze> (last accessed 16 April 2018).

Verdier, Yvonne, Coutume et destin : Thomas Hardy et autres essais, Paris: Gallimard, 1995.

\section{NOTES}

1. Escaping the charges for sexual assault held against him in the US he fled to France, arriving there in February 1978. The decision to shoot the film in France was also to avoid the risk of being arrested in the UK.

2. "On a conçu ce concept : faire résonner un film avec son époque. Par exemple, Tess, de Roman Polanski, un film en costumes se déroulant au XIX ${ }^{\text {ème }}$ siècle, témoigne, à sa façon, de la fin des années 1970 en France, puisque ce film si rural fut tourné juste au moment où la société rurale disparaissait dans notre pays" (Odicino).

3. "il est tout pénétré, habité par le sens de la vie en général, qui chez le grand romancier est quelque chose d'autre et quelque chose de plus que le sens de la vie des personnages qu'il crée." (Du Bos 854)

4. Schoenaerts came to be famous mostly after landing a part in the film of one of today's most prominent French film directors, Jacques Audiard. Indeed, the director of Un prophète ("A Prophet"), Audiard's most famous opus until now, chose the Belgian actor to play Ali in Rust and Bone (2012), a film also starring Marion Cotillard. Schoenaerts's remarkable performance allowed him to be awarded "Most Promising Actor" at the 2013 César Awards, the French national film awards earlier mentioned.

5. The film has had a fairly wide distribution in France, since, similarly to Schlesinger's 1967 adaptation produced by MGM, Vinterberg's is distributed by another big film company, Fox 
Searchlight, sister company to $20^{\text {th }}$ Century Fox. One slight difference though: contrary to MGM, Fox Searchlight mainly aims at distributing more independent productions.

6. Mulligan is familiar now to French spectators since she starred in big productions which achieved considerable success in France, such as The Great Gatsby (Baz Luhrman, 2013), Wall Street: Money Never Sleeps (Oliver Stone, 2010), or even in more stylish but appraised independent films such as Drive (Nicolas Winding Refn, 2011).

7. The publisher's promotional piece on the back cover starts with: "So young and pretty, Tess makes every man's head spin..." and finishes in equally sensational tones: "Will she endlessly be the victim of her shameful past?" Here, it is hard to resist the temptation of mentioning that this edition appeared in the wake of the tremendous commercial success of erotic bestseller Fifty Shades of Grey (E. L. James, 2011) in France. The heroine of the editorial phenomenon is offered a copy of Tess by the main male character, which, according to the marketing director of Hachette editions, apparently constituted reason enough to republish Tess with a new editorial line, a younger readership as target and a new marketing strategy explicitly using the connection, presenting Tess as "Fifty Shades heroine Anastasia Steele's favourite book." Hardy, for better - or worse, more likely. See www.20minutes.fr/culture/1117811-20130313-20130313-cinquantenuances-grey-vendre-classique

8. The "Black Moon" YA edition mentioned above is only an abridged version of the novel.

9. Of course, the praise of Hugo by Hardy was not limited to those comments. He also paid tribute to Hugo the poet in the "Imitations, etc." section of his Poems of Past and Present from 1901, in a poem simply called "From Victor Hugo." The poem is an adaptation of Hugo's "A une femme" ("To a woman"), published in Feuilles d'automne in 1831.

10. Jacques-Émile Blanche (1861-1942), Portrait de Marcel Proust, 1892, Huile sur toile - 73,5 x 60,5 $\mathrm{cm}$, Paris, Musée d'Orsay. <http://www.musee-orsay.fr/fr/collections/oeuvres-commentees/ recherche/commentaire_id/portrait-de-marcel-proust-29> (last accessed 16 April 2018).

11. "Blanche had been corresponding with Hardy for some time and had been trying to arrange to paint his portrait, but he didn't actually meet him until the afternoon on which this portrait sketch was painted [...] in an hour and a half" (Alley 57). See <http://www.tate.org.uk/art/ artworks/thomas-hardy-n03580/text-catalogue-entry> (last accessed 16 April 2018).

12. "July 1926. Note. - It appears that the Theory exhibited in 'The Well-Beloved' in 1892 - has been since developed by Proust still further: - 'Peu de personnes comprennent le caractère purement subjective du phénomène qu'est l'amour, et la sorte de création que c'est d'une personne supplémentaire, distincte de celle qui porte le même nom dans le monde, et dont la plupart des éléments son tirés de nous-même' (Ombre. I. 40.)

'Le désir s'élève, se satisfait, disparait - et c'est tout. Ainsi, la jeune fille qu'on épouse n'est pas celle dont on est tombé amoureux' (Ombre. II, 158, 159) \&c. see 'Marsyas.' Juillet 1926." (Taylor 92) 13. The most recent translation by Carol Clark refers to "the pattern of the stone-cutters" (Proust 345).

14. See also McGarry and Eells.

15. Even more remarkable than a French critic's appraisal of The Dynasts is the actual existence of a French translation of such a fantastical work. It was done by Yvonne Salmon and Philippe Neel and appeared in 1947 (Paris: Delamain et Boutelleau, collection Le Cabinet cosmopolite $n^{\circ}$ 90), no doubt a huge task which must have thus been carried out during WW2, quite adequately.

16. See also Morgan 47-48.

17. Roe further indicates that Larbaud made another similar comment in January 1925, placing Hardy next to other "European" writers: Proust, Pirandello, Ramon Gomez de la Serra.

18. See "Lettres anglaises", the series of chronicles published in the highly respectable magazine Mercure de France, written from 1896 to 1930 by Henry Davray, a French critic and translator and a starch supporter of British literature. For further analysis of these reviews, see Escuret 2013. 
19. “Aucune œuvre ne m'apparaît moins dogmatique. Il ne me semble possible d'en dégager ni une glorification ni une condamnation de l'amour libre [...]. Nous avons affaire à un penseur, qui est en même temps un artiste et un poète. Il observe et songe.

Sa méditation se double de sa sympathie. Une immense pitié emplit son cœur et bientôt cette pensée domine toutes les autres, cette humble pensée, plus profonde que tous les systèmes, et bien plus humaine aussi, bien plus touchante." (Roz 322-323)

20. La Revue des Deux Mondes had already published an article on Hardy in 1906, written by Firmin Roz whose translation of Jude the Obscure had appeared in 1901, as previously mentioned.

21. "La permanence du point de vue cosmique, l'entière fidélité à ce point de vue, ne comporte presque jamais l'extrême différenciation des œuvres entre elles; et c'est pourquoi, dans le riche aquarium de notre mémoire où tant de chefs-d'œuvre poursuivent une existence mystérieuse, l'impression globale que dépose l'ensemble de l'œuvre de Hardy est plus puissante encore que celle de l'un, quel qu'il soit, de ses plus grands livres envisagé séparément." (Du Bos 847)

22. $\mathrm{Du}$ Bos borrows the phrase from John Middleton Murry's "The Poetry of Mr. Hardy" published in The Athenaeum in 1919.

23. "ce sens de la vie en général dont Hardy nous aère et nous suffoque est toujours, en dernier ressort, tonifiant, salubre et comme chargé de sel” (Du Bos, 854).

24. "Au fond, Hardy invente, parallèlement à d'autres romanciers européens [...], un regard monographique." (Verdier 19) The quotation is from Claudine Fabre-Vassas and Daniel Fabre's preface to the book, "Du rite au roman : Parcours d'Yvonne Verdier".

25. Jean-Jacques Lecercle is one of the few to have noted the importance of Verdier's study of Hardy.

26. See also Deleuze's Dialogues II: “To fly is to trace a line, lines, a whole cartography. One only discovers worlds through a long, broken flight. Aglo-American literature constantly shows these ruptures, these characters who create their line of flight, who create through a line of flight. Thomas Hardy, Melville, Stevenson, Virginia Woolf, Thomas Wolfe, Lawrence, Fitzgerald, Miller, Kerouac. In them everything is departure, becoming, passage, leap, daemon, relationship with the outside. They create a new Earth; but perhaps the movement of the earth is deterritorialization itself. American literature operates according to geographical lines: the flight towards the West, the discovery that the true East is in the West, the sense of the frontiers as something to cross, to push back, to go beyond. The becoming is geographical. There is no equivalent in France. The French are too human, too historical, too concerned with the future and the past. They spend their time in in-depth analysis. They do not know how to become, they think in terms of historical past and future." (Deleuze \& Parnet 36-37).

27. Georges Devereux, Reality and Dream: Psychotherapy of a Plains Indian, New York: International University Press, 1951.

\section{ABSTRACTS}

Starting with the role of popular culture and more specifically cinema in the possible dissemination of Hardy's name in the perceptions of a French audience, we briefly evoke the existing translations of Hardy's works to look back at their reception in his own time. We evoke in particular the major French writers who have been most commonly associated with him as well as the contemporary critics who celebrated his work. We trace the presence of Hardy in French criticism throughout the $20^{\text {th }}$ century up to the most recent academic activities, heralded 
by the French Association for Thomas Hardy Studies (FATHOM). Through such connections, it is (unsurprisingly) the universal strength of Hardy's writing that stands out as a key feature in French critics' appraisal of his work, both in his time and today.

Cet article s'intéresse tout d'abord au role qu'a pu jouer la culture populaire, et plus spécifiquement le cinéma, dans la dissémination possible du nom de Thomas Hardy dans les représentations du public français. Il évoque ensuite brièvement les traductions françaises des œuvres de Hardy et leur réception de son temps, en s'arrêtant plus particulièrement sur les grands auteurs français qui lui ont souvent été associés ainsi que sur les critiques contemporains ayant célébré son écriture. Il est ainsi possible de suivre le fil de cette critique hardyenne française tout au long du vingtième siècle jusqu'aux activités de recherche les plus récentes, portées ces dernières années par FATHOM, French Association for Thomas Hardy Studies. En tissant ces liens, on voit (sans surprise) se révéler la force universelle de l'écriture de Hardy, élément central de la célébration critique de son œuvre en France, tant aujourd'hui qu'à son époque.

\section{INDEX}

Mots-clés: France, réception, traduction, littérature française, critique littéraire, cinéma, culture populaire, Proust (Marcel), Zola (Emile), Hugo (Victor)

Keywords: France, reception, translation, French literature, literary criticism, cinema, popular culture, Proust (Marcel), Zola (Emile), Hugo (Victor)

oeuvrecitee Jude the Obscure, Tess of the d'Urbervilles, Far from the Madding Crowd

\section{AUTHORS}

\section{PEGGY BLIN-CORDON}

Peggy Blin-Cordon, holder of the "agrégation" in English Language and Literature, is a Lecturer at University of Cergy Pontoise, where she teaches literature and translation. A founding member and the treasurer of the FATHOM association (French Association for Thomas Hardy Studies), she wrote a thesis on generic experiments in the novels of Thomas Hardy. She specialises in Hardy and literary genres and also works on the influence of the publishing practice on $19^{\text {th }}$ century fiction.

\section{LAURENCE ESTANOVE}

Laurence Estanove teaches at Université Paris Descartes. In 2008, she completed and defended her PhD thesis entitled The Dynamics of Disillusionment in Hardy's Poetry. She has published on Hardy's verse as well as his fiction and other writings. In parallel, she conducts research on contemporary popular music. 